\title{
Clinical and Bacteriological features of spontaneous bacterial peritonitis in Malagasy patients with Cirrhosis
}

\section{Andry Lalaina Rinà Rakotozafindrabe}

University hospital Joseph Raseta Befelatanana

Chantelli lamblaudiot Razafindrazoto ( $\square$ iamblaudiotchantelli@yahoo.com )

University hospital Joseph Raseta Befelatanana

Anjaramalala Sitraka Rasolonjatovo

University hospital Joseph Raseta Befelatanana

Jean Désiré Ezra Lantonirina

University hospital Joseph Raseta Befelatanana

Jolivet Auguste Rakotomalala

University Hospital Mahavoky Atsimo

Nitah Harivony Randriamifidy

University hospital Joseph Raseta Befelatanana

\section{Sonny Maherison}

University hospital Joseph Raseta Befelatanana

Behoavy Mahafaly Ralaizanaka

University Hospital Andrainjato

Tovo Harimanana Rabenjanahary

University hospital Joseph Raseta Befelatanana

Rado Manitrala Ramanampamonjy

University hospital Joseph Raseta Befelatanana

\section{Research Article}

Keywords: Ascites, liver cirrhosis, infection, spontaneous bacteria peritonitis, Madagascar

Posted Date: April 13th, 2021

DOI: https://doi.org/10.21203/rs.3.rs-418435/v1

License: (c) (1) This work is licensed under a Creative Commons Attribution 4.0 International License.

Read Full License 


\section{Abstract}

Background: Spontaneous bacterial peritonitis (SBP) represent frequent and serious complications in cirrhosis patients with ascites. Our aim was to describe the clinical and bacteriological characteristics of SBP in Madagascar.

Methods: This is a 21-month prospective study between January 2018 and October 2019, including hospitalized patients with cirrhosis, with clinical and biological symptoms of SBP.

Results: Thirty-three patients were included. The mean age was $48.09 \pm 13.55$ years (extremes: $19-78$ years), the sex ratio was 3.12. Abdominal pain (55\%), fever (36\%), diarrhea (6\%), hepatic encephalopathy $(18 \%)$ are the most common symptoms. Gastrointestinal bleeding $(18.18 \%)$ was the main risk factor to SBP. SBP was community-acquired in $87.88 \%$ of cases. A culture of ascites fluid was positive for 9 patients (27.27\%). The infectious agents found were Escherichia coli (12.10\%), Klebsiella pneumoniae (3\%), Pseudomonas (3\%), Streptococcus mitis (9.1\%). Escherichia coli were wild with one case resistant to Ceftriaxone. The Klebsiella were multidrug resistant. The other two pathogens did not show resistance. After antibiotic therapy adapted to the antibiogram, healing was observed in 26 patients (78.78\%). Seven patients $(21.22 \%)$ died from various complications. All deceased patients had bacteria identified in ascites fluid.

Conclusion: SBP defined according to clinical and biological criteria is apparently sterile in the majority of cases. Gram-negative bacteria were the major pathogens involved in SBP in cirrhotic patients. Escherichia coli and streptococcus were the most common pathogen isolated. Bacteriological study is essential to adapt antimicrobial to multidrug-resistant bacteria.

\section{Background}

Spontaneous bacteria peritonitis (SBP) is a common and serious infectious complication of advanced liver disease with portal hypertension. In-hospital prevalence varies from 10 to $30 \%$ [1, 2]. SBP is a cause of high morbidity and mortality in patients with cirrhosis. Mortality during SBP has decreased markedly in recent years, but remains high with an in-hospital mortality rate ranging from 10 to 50\% [2-6]. Early treatment of SBP could decrease the death rate of cirrhotics by $30 \%[2,5,6]$. Knowledge of bacterial ecology is essential for a well-adapted antibiotic therapy. No previous studies have been done on the pathogens commonly responsible for SBP in Madagascar. The aim of this study was to describe the clinical and bacteriological characteristics of SBP in Madagascar.

\section{Materials And Methods}

This is a prospective and descriptive study over 21 months (January 2018 to October 2019), carried out at University Hospital of Joseph Raseta Befelatanana, Antananarivo. All patients with hospitalized decompensated cirrhosis with clinical symptoms in favor of SBP were recruited. the study included, all patients with clinical symptoms of SBP and a polymorphonuclear neutrophils leukocytes (PMN) count in 
ascitic fluid greater than 250 cells/mm3 or bacterascites associated with clinical symptoms of SBP. Bacterascites is defined by a PMN count of less than 250 cells $/ \mathrm{mm}$ with a positive culture. All patients with secondary bacterial peritonitis were excluded. Demographic data (gender and age), clinical data (antecedents, causes of cirrhosis, clinical symptoms, factors risk SBP, complications, communityacquired or nosocomial SBP), biological, cytological and bacteriological data of ascites fluid (serum creatinine, Child-Pugh classification, ascites fluid protein level, bacterascites, ascites fluid culture and antibiogram) and the therapeutic data were collected. Community-acquired SBP was defined as an infection diagnosed within the first $48 \mathrm{~h}$ of admission to hospital without any prior contact with health care within 90 days, where as a diagnosis made more than $48 \mathrm{~h}$ after hospitalization was defined as nosocomial SBP.

Diagnostic paracentesis was been done immediately of any suspicion of SBP, under aseptic conditions. The ascites fluid was received on 2 dry tubes for a biochemical, cytological and bacteriological examination. The bacteriological examination was carried out on solid media (chocolate agar and blood incubated under $\mathrm{CO} 2$ at $37^{\circ} \mathrm{C}$ ) and liquids media (brain heart broth). Concomitant culture was done on a blood culture bottle. The samples are sent to the laboratory in less than $2 \mathrm{~h}$. In the event of a positive culture, the identification of the pathogen and the antibiogram was carried out. In case of negative culture within 48-72h, the vials were preserved until the 5th day.

The data were analyzed on the software Epi-Info version 7.2.

\section{Results}

During the study period (January 2018 to October 2019), we collected 129 patients with cirrhosis of which 46 patients had presented one or more clinical symptoms of SBP. We excluded 13 patients, of which 4 of the excluded patients had a secondary bacterial peritonitis and the 9 others presented symptoms in favor of SBP but the PMN leukocytes count $<250$ cells $/ \mathrm{mm} 3$ without bacterascites. The flowchart for patient enrollment was shown in Fig.1. Thirty-three patients were selected, giving an inhospital prevalence of $25.58 \%$.

\section{General characteristics and clinical-biological presentations}

Among the 33 patients, 25 patients $(75.76 \%)$ were male and 8 (24.24\%) female. Their ages ranged from 19 to 78 years and the mean age was $48.09 \pm 55$ years. A notion of previous decompensation was found in $87.88 \%(n=29)$. Alcohol (13 patients, 39.39\%) was the most common cause of cirrhosis, followed by hepatitis B virus (HBV) (12 patients, 36.36\%). Twenty-six patients (78.79\%) had a Child-Pugh C. Abdominal pain (30 patients, 90.91\%), fever (25 patients, $75.76 \%$ ) and diarrhea (7 patients, $21.21 \%$ ) were the most common presenting symptoms of an SBP. Gastrointestinal bleeding was the most common risk factor (6 patients, 18.18\%). SBP was community-acquired in 29 patients $(87.88 \%)$ and nosocomial in 4 patients $(12.12 \%)$. General characteristics and clinico-biological presentations of 33 patients with SBP are shown in Table 1. 


\section{Bacteriological characteristics and antimicrobial susceptibility}

Culture of ascites fluid was sterile in $72.73 \%$ (24 patients). Nine patients $(27.27 \%)$ had a positive culture. The proportion of Gram-negative bacteria and Gram-positive bacteria were $66.67 \%$ ( 6 patients) and $33.33 \%$ (3 patients) respectively. Escherichia coli was the major pathogen agent (4 patients, $44.44 \%$ ), followed by Streptococcus mitis (3 patients, 33.33\%), Klebsiella pneumoniae (1 patient, $11.11 \%$ ) and Pseudomonas (1 patient, 11.11\%). Escherichia coli and Streptococcus were sensitive to first-line antimicrobial for SBP treatment (Quinolones, Cephalosporins and Penicillins). A case of Escherichia coli resistant to cephalosporins (25\%) was observed. Pseudomonas was sensitive to quinolones and penicillins but resistant to cephalosporins. Klebsiella was multidrug resistant. Bacteriological characteristics and antimicrobial susceptibility are shown respectively in Table 2 and 3.

\section{Management and in-hospital evolution}

Quinolones (19 patients, 57.58\%) and cephalosporins (8 patients, $24.24 \%$ ) were the most common probabilistic antimicrobial prescribed. It was adapted secondarily according to the pathogens and the antibiogram. The mean duration of antibiotic therapy was $7 \pm 2.98$ days (Extremes : $2-14$ days). The outcome was favorable in $60.61 \%$ (20 patients). Five patients $(15.15 \%$ ) died from severe sepsis, acute renal failure and gastrointestinal bleeding. All deceased patients had bacteria identified in ascites fluid. Management and in-hospital evolution are shown in Table 4.

\section{Discussion}

This was the first study on the bacteriological profile of SBP in Madagascar. This study was essential because it had made it possible to establish the bacteriological and clinical profile of SBP in Malagasy patients with cirrhosis. This study had limitations. This is a single-center study and limited to those of inpatients. In-hospital prevalence of SBP was $25.58 \%$, which corresponded to data from Western literatures (10-30\%) [1, 2, 7]. Duah et al (Ghana, 2019) found a prevalence of $25.24 \%$, similar to our study [8]. While, Oladimeji et al (Nigeria, 2013) reported a very high in-hospital prevalence at $67.7 \%$ [9]. These results are explained by the low number of the cirrhotic population during the study period, a high rate of culture positive (66.7\%). Abdominal pain, fever and diarrhea were the most common symptoms during SBP. This finding has been reported by many authors (Setoyama et al; Shi et al) [10, 11]. The presence of these symptoms should alarm the clinician, suggesting the introduction of a probabilistic antibiotic therapy, without waiting for the results of the samples. Despite the low prevalence of hepatic encephalopathy in our series $(6.06 \%)$, many studies reported a high rate of it during SBP $[10,11]$. The presence of hepatic encephalopathy should systematically seek an SBP. Bacterial translocation is increased in gastrointestinal bleeding in patients with cirrhosis. Gastrointestinal bleeding was a risk factor to SBP [12-15]. Primary prevention of SBP with prophylactic antimicrobials should be initiated in gastrointestinal bleeding in patients with cirrhosis [2, 16-18]. In our study, gastrointestinal bleeding was present in only 6 patients $(18.18 \%)$ with SBP. 
In recent years, many authors have reported an upsurge in nosocomial SBP [11, 19-21]. Shi et al (2017) found a nosocomial SBP rate of $44.9 \%$ [11]. Ning et al (2018) reported nosocomial SBP in $47.8 \%$ of patients [18]. Other previous studies (Campillo et al in 2002; Cheong et alin 2009) also had high rates of nosocomial SBP $[20,21]$. Contrary to published data, the nosocomial SBP rate was low $(12.12 \%)$ in this present study. These high rates of nosocomial SBP could be explained in part by the fact that the patients included in these studies had frequent previous hospitalizations and had long hospital stays. In this study, community-acquired SBP occupied the majority of cases (87.88\%).

In patients hospitalized with decompensated cirrhosis, $6.06 \%$ had bacterascites. This was comparable to the data in the literature $(11 \%)[2,16]$. It could be due to transient colonization of ascitic fluid, or to an early phase of SBP [16]. Bacterascites should be considered an SBP in the presence of suggestive clinical symptoms, requiring antibiotic therapy from the outset. According to the literature, 20 to $30 \%$ of cultures performed were negative $[2,16,17,22]$. They are higher $(72.73 \%)$ in this study. The absence of the pathogen, although frequently found, does not eliminate SBP $[16,23]$. Only $27.27 \%$ of the patients in our series had a positive culture. These results were comparable to those of Xiao et al (South Korea) [24] and Sanjaya et al (United States) [25] with a respective rate of $21.49 \%$ and $20 \%$. Among the positive cultures, the majority of the bacteria found were Gram negative bacteria (66.67\%). The other authors observed similar results: Oladimeji et al (Nigeria, 68.1\%) [9], Attia et al (Cote d'Ivoire, 70\%) [7], Piroth et al (France, 66\%) [3], Shi et al (China, 50.6\%) [11], Cheong et al (South Korea, 57.2\%) [21], Reginato et al (Brazil, $57.4 \%)[26]$.

This is explained by the characteristic of digestive pathogens, of which Gram-negative bacteria are predominant. Escherichia coli (44.44\%), Streptococcus mitis (33.33\%), Klebsiella (11.11\%) and Pseudomonas (11.11\%) were the pathogens identified. This confirms those that have already been described; Dever et al (United States) [23], de Attia et al (Cote d'Ivoire) [7], Duah et al (Ghana) [8, 12] and Mohamed et al (Egypt) [27]. Since SBP's mechanism in cirrhotics is bacterial translocation, this explains these findings. The recommendations on treatment of SBP targeting Gram-negative bacteria as first-line may therefore be applicable. Two cases of Escherichia coli resistant to antibiotics were identified, including one case of resistance to cephalosporins and one case to sulfamethoxazole/trimethoprim. Kirplani et al (Pakistan) [28] found cases of Escherichia coli resistant to Ceftriaxone (32\%) and Sulfamethoxazole/trimethoprim (10.9\%). Another study by Ding et al showed similar results [14]. The frequent and inadequate use of cephalosporins and sulfamethoxazole/trimethoprim in Madagascar may explain these facts [29]. The use of quinolones and amoxicillin-clavulanic acid are suitable alternatives in this case. Pseudomonas was resistant to cephalosporin and Sulfamethoxazole/Trimethoprim. It was most often a nosocomial germ and also had a natural resistance to certain antibiotics including cephalosporin, nalidixic acid, Fosfomycin, sulfonamides [30]. A case of nosocomial infection with Klebsiella has been identified. He was multidrug resistant and was only susceptible to Amikacin. Several authors (Nousbaum et al and Ariza et a) reported that $25 \%$ to $50 \%$ of germs during nosocomial SBP were resistant to the usual antibiotics $[2,16,31]$. This reiterates the need for a systematic performance of a bacteriological examination with antibiogram in the face of any suspicion of an SBP. 
Indeed, clinicians must be vigilant in the face of the emergence of multidrug-resistant pathogens. Current recommendations called for the use of Cefotaxime $(2 \mathrm{~g} / 8 \mathrm{~h})$ for 5 days, either amoxicillin/clavulanic acid $(1 \mathrm{~g} / 8 \mathrm{~h})$ for 7 days, or Ofloxacin (400mg/day) for 7 days, in case of community-acquired SBP. Piperacillin/tazobactam or Carbapenem are recommended in case of nosocomial SBP. The initial antimicrobials will be adapted according to the antibiogram $[16,32,33]$. In this study, quinolones were the most used, probabilistically, (57.58\%) with a mean duration of $7 \pm 2.98$ days (Extreme: 2 to 14 days). Given the high prevalence of Gram-negative bacteria found in this study, the initial antimicrobial with quinolones was well suited.

The effectiveness of antibiotic therapy is defined according to the International Ascites Club as a decrease of at least $25 \%$ in the level of PMN in ascites after $48 \mathrm{~h}$ of treatment $[2,16]$. This effectiveness will dictate the duration of treatment, explaining the variation in the duration of antibiotic therapy in this study.

In-hospital mortality rate was $15.15 \%$. The deceased patients all had positive cultures. It was comparable compared to some studies (10 to 50\%) [2-6, 16, 21, 34-37], while it was lower compared to the others studies: Heo et al (21.9\%) [34], Oliveira et al (41\%) [35], Tandon and Garcia-Tsao (29\%) [4], Poca et al (28\%) [36, 37], Follo et al (24\%) [38] and Cheong et al (49\%) [21]. The difference in the findings can be explained, on the one hand, by the difference between the study populations; on the other hand, the multitude of management structures. However, SBP remains an absolute medical emergency, with a poor prognosis. The speed of the diagnosis of SBP, the susceptibility of pathogens to probabilistic antimicrobials as well as the precocity of the treatment can be key elements for the success of the management of SBP.

\section{Conclusion}

This was the first study on the bacteriological profile of SBP in Madagascar. In-hospital prevalence of SBP was $25.58 \%$. The clinical symptoms are similar to those described in the literature. Abdominal pain and fever were the main warning signs for an SBP. SBP was predominantly community-based. SBP defined according to clinical and biological criteria is apparently sterile in the majority of cases. Gramnegative bacteria were the major pathogens involved in SBP in cirrhotic patients. Escherichia coli and streptococcus were the most common pathogen isolated. The pathogen isolated were globally sensitive to the antimicrobial usually recommended by the current guidelines. A larger-scale study will be needed to develop a national SBP guideline.

\section{Abbreviations}

SBP: Spontaneous Bacterial Peritonitis, SD: Standard Deviation, HVB: Hepatitis Virus B, HVC: Hepatitis Virus C, PMN: Polymorphonuclear leukocytes, S: Sensibility ; R: Resistance.

\section{Declarations}




\section{Ethical approval and consent to participate}

The study was approved by the hierarchical heads of University Hospital Joseph Raseta Befelatanana, Antananarivo. Written informed consent was obtained from all participants.

\section{Consent for publication}

Written consent was obtained from all participants.

\section{Availability of data and materials}

Data available on request from the corresponding author.

\section{Competing interests}

The author declare that they have no competing interests.

\section{Funding}

None.

\section{Authors' contributions}

ALRR, CIR and ASR: were the main contributors to drafting the manuscript. JDEL: contributed to data collection. JAR, NHR, SM, BMR, THR: contributed in management of patients in hospital and performed the final manuscript. RMR : contributed to study design and performed the final manuscript. All authors have read and approved the manuscript.

\section{Acknowledgments}

We gratefully acknowledge the work of members of the unity of Gastroenterology and unity of Biology and Microbiology, University Hospital Joseph Raseta Befelatanana, Antananarivo, Madagascar. Written informed consent was obtained from all participants.

\section{References}

1. Ripoll C, Groszmann R, Garcia-Tsao G, Grace N, Burroughs A, Planas R, et al. Hepatic venous pressure gradient predicts clinical decompensation in patients with compensated cirrhosis. Gastroenterology. 2007;133: 481-8.

2. Nousbaum JB, Cadranel JF, Nahon P, Nguyen Khac E, Moreau R, Thévenot T, et al. Diagnostic accuracy of the Multistix 8SG reagent strip in diagnosis of spontaneous bacterial peritonitis. Hepatology. 2007; 45 : 1275-81.

3. Piroth L, Pechinot A, di Martino V, Hansmann Y, Putot A, Patry I, et al. Evolving epidemiology and antimicrobial resistance in spontaneous bacterial peritonitis: a two-year observational study. BMC 
Infect Dis. 2014; 14: 287.

4. Tandon P, Garcia-Tsao G. Renal dysfunction is the most important independent predictor of mortality in cirrhotic patients with spontaneous bacterial peritonitis. Clin Gastroenterol Hepatol. 2011; 9: 260265.

5. Evans LT, Kim WR, Poterucha JJ, Kamath PS. Spontaneous bacterial in asymptomatic out patients with cirrhotic ascites. Hepatology. 2003; 37:897-901.

6. Silvaine C, Chagneau C. Complication de l'hypertension portale chez l'adulte : les conclusions de la conférence de consensus (Paris, décembre 2003). Med ther. 2004; 10(4) : 252-62.

7. Attia KA, Yoman TN, Sowadogo A, Feye-Kette H, Mahamad A, Bathaix-Yao F et al. Infection spontanée du liquide d’ascite chez les cirrhotiques: évaluation de deux procédures de culture du liquide d'ascite. Med Mal Inf. $2002 ; 32$ : 184-9.

8. Amoakou D, Kofi NN. Prevalence and predictors for spontaneous bacterial peritonitis in cirrhotic patients with ascites admitted at medical block in Korle-Bu Teaching Hospital, Ghana. Pan Afr Med J. 2019; 33: 35.

9. Oladimeji AA, Temi AP, Adekunle AE, Taiwo RH, Ayokunle DS. Prevalence of spontaneous bacterial peritonitis in liver cirrhosis with ascites. Pan Afr Med J. 2013; 15: 128.

10. Setoyama H, Tanaka M, Sasaki Y. Treatment of spontaneous bacterial peritonitis. In Clinical Investigation of Portal Hypertension; Obara, K., Ed.; Springer Singapore: Singapore, China, 2019 ; pp. 517-522.

11. Shi L, Wu D, Wei L, Liu S, Zhao P, Tu B et al. Nosocomial and community-acquired spontaneous bacterial peritonitis in patients with liver cirrhosis in China : Comparative Microbiology and Therapeutic Implication. Sci Rep. 2017; 7: 46025.

12. Amoakou D, Kofi NN. Spontaneous bacterial peritonitis among adult patients with attending Korle-Bu teaching Hospital in Ghana. Ghana Med J. 2019; 53(1) :37-43.

13. Dutta S, Chawla S, Srivastava S, Loomba P. Spontaneous bacterial peritonitis : A review. IJCMP. $2018 ; 4: 3872-76$.

14. Ding X, Yu Y, Chen M, Wang C, Kang Y, Lou J. Causative agents and outcome of spontaneous bacterial peritonitis in cirrhotic patient: community-acquired versus nosocomial infections. BMC infection Diseases. 2019; 19: 463.

15. Bajaj JS, Tandon P, O'Leary JG, Wong F, Biggins SW, Garcia-Tsao G et al. Outcome in patient with cirrhosis on Primary Compared to secondary Prophylaxis for Spontaneous Bacterial Peritonitis. Amj Gastroenterol. 2019; 114(4): 599-606.

16. Nousbaum Infection du liquide d'ascite : Diagnostic, traitement et prévention. Hépatologie (POST'U). $2015 ; 99-105$.

17. European Association for the Study of the Liver. Clinical Practice on the management of ascites. Spontaneous bacterial peritonitis and Hepatorenal syndrome in Cirrhosis. J hepatol. $2010 ; 53$ :397 
18. European Association for the Study of the Liver. Management of complication of cirrhosis in patient awaiting liver transplantation, J Hepatol. 2005; 42 (1): S124-S133.

19. Ning N-Z, Li T, Zhang J-L, Qu F, Huang J, Liu X et al. Clinical and bacteriological features and prognosis of ascitic fluid infection in Chinese patients with cirrhosis. BMC Inf Dis. 2018; 18: 253.

20. Campillo B, Richardet JP, Kheo T, Dupeyron C. Nosocomial spontaneous bacterial peritonitis and bacteremia in cirrhotic patients: impact of isolate type on prognosis and characteristics of infection. Clin Infect Dis. 2002; 35(1): 1-10.

21. Cheong HS, Kang Cl, Lee JA, Moon SY, Joung MK, Chung DR et al. Clinical significance and outcome of nosocomial acquisition of spontaneous bacterial peritonitis in patients with liver cirrhosis. Clin Infect Dis. 2009; 48(9): 1230-6.

22. Siersema PD, de Marie S, van Zeij JH, Bac JD, Wilson JH. Blood culture Bottles are superior to lysis centrifugation tubes for bacteriological diagnosis of spontaneous bacterial peritonitis. J Clinical Microbiology. 1992 : 667-669.

23. Dever JB, Sheikh MY. Spontaneous bacterial Peritonitis: bacteriology, diagnostic, treatment, Risk factor and prevention. Aliment Pharmacol Ther. 2015; 41(11): 1116-31.

24. Xiao L, Nu EG, Sha NY, Liu H, Zhang YX. PP-043: Clinical analysis of 145 cases with Spontaneous bacterial peritonitis. Intern J infection Disease. 2009; 12 (3): 68.

25. Sunjaya DB, Lennon RJ, Shah VH, Kamath PS, Simonetto DA. Prevalence and Predictor of Thirdgeneration Cephalosporine resistance in the empirical treatment of spontaneous bacterial peritonitis. Mayo Clin Proc. 2019 ; 94(8): 1499-1508.

26. Reginato TJ, Oliveira MJ, Moreira LC, Lamanna A, Acencio MMP, Antonangelo L. Characteristics of ascitic fluid from patients with suspected spontaneous bacterial peritonitis in emergency units at a tertiary hospital. Sao Paulo Med J. 2011; 129(5): 315-9.

27. Mohamed, Atef M, Alsebaey A, Elhabshy MM, Salama M. Combined spontaneous bacterial empyema and peritonitis in cirrhotic patients with ascites and hepatic hydrothorax. Arab J Gastroenterol. 2017; 18(2): 104-107.

28. Kiplani PD, Laila TQ, Ochani RK, Memon ZA, Tahir SA, Seetlani NK et al. Recognition of antibiotic resistance in spontaneous bacterial peritonitis caused by Escherichia Coli in Liver Cirrhotic patient in Civil Hospital Karachi Pakistan. Cureus 2019 11(7) : e5284.

29. Randriatsarafara FM, Ralamboson J, Rakotoarivelo R, Raherinandrasana A, Andrianasolo R. Consommation d'antibiotique au CHU d'Antananarivo : Prévalence et défis stratégique. Sante Publique. 2015, 2 (27) : 249-255.

30. Avril JL, Dabernat H, Denise F, Montail H. Bacteriological clinic. Marketing. 1992; 2: 275-77.

31. Ariza X, Castellot J, Lora-Tamayo J, Girbau A, Salord S, Rota R et al. Factor for resistance to ceftriaxone and its impact on mortality community healthcare and nosocomial spontaneous bacterial peritonitis. J Hepatol. 2012; 56(4): 825-32.

32. Amoako D, Kofi NN. Prevalence and predictor for spontaneous bacterial peritonitis in cirrhotic patients with ascites admitted at medical bloc in Korle-Bu teaching Hospital Ghana. Pan Afr Med J. 
$2019 ; 33: 35$.

33. Heo J, Seo YS, Yim HJ, Hahn J, Park SH, Ahn SH et al. Clinical feature and prognostic of spontaneous bacterial peritonitis in Korea patient with lever cirrhosis: Multicenter retrospective study. Gut Liver. 2009; 3(3): 197-204.

34. Oliveira AM, Branco JC, Barosa R, Rodrigues JA, Ramos L, Martins A et al. Clinical and microbiological characteristics associated with mortality in spontaneous bacterial peritonitis: a multicenter cohort study. Eur J Gastroenterol Hepatol. 2016; 28(10):1216-22.

35. Poca M, Alvarado-Tapias E, Conceptión M, Pérez-Cameo C, Canete N, Gich I et al. P0190: predictive model of mortality in cirrhotic patients with high risk spontaneous bacterial peritonitis. $\mathrm{J}$ Hepatol. 2015; 62: S375.

36. Poca M, Alvarado-Tapias E, Concepción M, Pérez-Cameo C, Canete N, Gich I et al. Predictive model of mortality in patients with spontaneous bacterial peritonitis. Aliment Pharmacol Ther. 2016; 44(6): 629-37.

37. Follo A, Llovet JM, Navasa M, Forns X, Francitorra A, Rimola A et al. Renal impairment after spontaneous bacterial peritonitis in cirrhosis: incidence, clinical course, predictive factors and prognosis. Hepatology. 1994; 20(6): 1495-501.

\section{Tables}

Table 1. General characteristics and clinico-biological presentations of 33 Malagasy patients with SBP 


\begin{tabular}{|c|c|}
\hline Parameters & $n(\%)$ \\
\hline Male/Female & $25(75,76) / 8(24,24)$ \\
\hline Age, mean $\pm S D$ & $48,09 \pm 13,55$ \\
\hline Age group (years) & \\
\hline $1<30$ & $2(6,06)$ \\
\hline & $8(24,24)$ \\
\hline 1. $[30-40[$ & $7(0121)$ \\
\hline 1. $[40-50[$ & $1(21,21)$ \\
\hline 1. $[50-60[$ & $11(33,33)$ \\
\hline 1. ․ 60 & $5(15,15)$ \\
\hline Notion of previous decompensation, Yes/No & $29(87,88) / 4(12,12)$ \\
\hline Cause of liver cirrhosis & $13(39,39)$ \\
\hline 1. Alcohol & $12(36,36)$ \\
\hline 1. HVB & $4(12,12)$ \\
\hline 1. HVC & $4(12,12)$ \\
\hline $\begin{array}{l}\text { 1. Alcohol + HVB } \\
\text { Child-Pugh B/C }\end{array}$ & $7(21,21) / 26(78,79)$ \\
\hline Initial presenting symptoms & $25(75,76)$ \\
\hline 1. rever & $30(90,91)$ \\
\hline 1. Abdominal pain & $7(21,21)$ \\
\hline 1. Diarrhea & $2(6,06)$ \\
\hline 1. Hepatic Encephalopathy & $2(6,06)$ \\
\hline 1. Gastrointestinal bleeding & $1(3,03)$ \\
\hline 1. Jaundice & $5(15,15)$ \\
\hline $\begin{array}{l}\text { 1. Others } \\
\text { Ascites, moderate/large volume }\end{array}$ & $7(21,21) / 26(78,79)$ \\
\hline Risk Factors & $6(18,18)$ \\
\hline 1. Gastrointestinal bleeding & $1(3,03)$ \\
\hline 1. Paracentesis & $1(3,03)$ \\
\hline 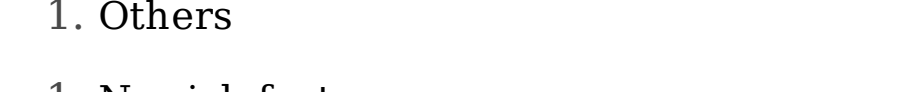 & $25(75,76)$ \\
\hline $\begin{array}{l}\text { 1. No risk factor } \\
\text { Community-acquired SBP/Nosocomial SBP } \\
\text { Serum creatinine }(\mathrm{mmol} / \mathrm{L}), £ 100 />100\end{array}$ & $\begin{array}{l}29(87,88) / 4(12,12) \\
25(75,76) / 8(24,24)\end{array}$ \\
\hline Macroscopic aspect of ascites fluid & $20(60,61)$ \\
\hline 1. Citrin & $9(27,27)$ \\
\hline 1. Irouble & $4(12,12)$ \\
\hline
\end{tabular}


1. Hematic

Protein in ascites fluid $(\mathrm{g} / \mathrm{L})$

1. $<10$

$7(21,21)$

$9(27,27)$

1. [10-25]

$17(51,52)$

1. $>25$

1. $<250+$ bacterascites

1. [250-500]

1. $>500$

Ascites culture

1. Positive

1. Negative

$24(72,73)$

SBP : Spontaneous Bacterial Peritonitis, SD : Standard Deviation, HVB : Hepatitis Virus B, HVC : Hepatitis Virus C, PMN: Polymorphonuclear leukocytes

Table 2. Bacteriological characteristics of 33 Malagasy patients with SBP

\begin{tabular}{lc}
\hline Bacteria & $n(\%)$ \\
\hline No Bacteria & $24(72,73)$ \\
Presence of bacteria & $9(27,27)$ \\
Gram-negative bacteria/Gram-positive bacteria & $6(66,67) / 3(33,33)$ \\
Escherichia coli & $4 / 9(44,44)$ \\
Klebsiella & $1 / 9(11,11)$ \\
Pseudomonas & $1 / 9(11,11)$ \\
Streptococcus Mitis & $3 / 9(33,33)$ \\
\hline
\end{tabular}

Table 3. Antimicrobial susceptibility 


\begin{tabular}{|c|c|c|c|c|}
\hline Antibiotics & $\begin{array}{c}\text { Escherichia coli }(\mathrm{n}=4) \\
\text { S/R }\end{array}$ & $\begin{array}{c}\text { Klebsiella } \\
(\mathrm{n}=1) \\
\mathrm{S} / \mathrm{R}\end{array}$ & $\begin{array}{c}\text { Streptococcus } \\
(\mathrm{n}=3) \\
\mathrm{S} / \mathrm{R}\end{array}$ & $\begin{array}{c}\text { Pseudomonas }(\mathrm{n}=1) \\
\mathrm{S} / \mathrm{R}\end{array}$ \\
\hline Penicillin & $4 / 0$ & $0 / 1$ & $3 / 0$ & $1 / 0$ \\
\hline Cephalosporins & $3 / 1$ & $0 / 1$ & $3 / 0$ & $0 / 1$ \\
\hline Carbapenem & $4 / 0$ & $0 / 1$ & $3 / 0$ & $1 / 0$ \\
\hline Aminoglycosides & $4 / 0$ & $1 / 0$ & $3 / 0$ & $1 / 0$ \\
\hline Cyclin & $4 / 0$ & $0 / 1$ & $1 / 2$ & $1 / 0$ \\
\hline Quinolone & $4 / 0$ & $0 / 1$ & $3 / 0$ & $1 / 0$ \\
\hline $\begin{array}{l}\text { Sulfonamides } \\
\text { Nalidixic acid }\end{array}$ & $\begin{array}{l}3 / 1 \\
4 / 0\end{array}$ & $\begin{array}{l}0 / 1 \\
0 / 1\end{array}$ & $\begin{array}{l}2 / 1 \\
3 / 0\end{array}$ & $\begin{array}{l}0 / 1 \\
1 / 0\end{array}$ \\
\hline Chloramphenicol & $4 / 0$ & $0 / 1$ & $3 / 0$ & $1 / 0$ \\
\hline Nitrofuran & $4 / 0$ & $0 / 1$ & $3 / 0$ & $1 / 0$ \\
\hline Fosfomycin & $4 / 0$ & $0 / 1$ & $3 / 0$ & $1 / 0$ \\
\hline Colistin & $4 / 0$ & $0 / 1$ & $3 / 0$ & $1 / 0$ \\
\hline
\end{tabular}

S : Sensibility ; R : Resistance

Table 4. Management and in-hospital evolution of 33 Malagasy patients with SBP

\begin{tabular}{lc}
\hline Parameters & $n(\%)$ \\
\hline Antibiotic therapy & $19(57,58)$ \\
1. Quinolones (Ciprofloxacin/Levofloxacin/Norfloxacin) & $3(9,09)$ \\
1. Amoxicillin-clavulanic acid & $8(24,24)$ \\
1. $3^{\text {rd }}$ generation Cephalosporin (Ceftriaxone) & $3(9,09)$ \\
1. Others & $7 \pm 2,98(2-14)$ \\
Duration of antibiotic therapy, means (extremes) & $20(60,61)$ \\
In-hospital evolution & $2(6,06)$ \\
1. Favorable & $5(15,15)$ \\
1. Persistence of symptom & $6(18,18)$ \\
1. Death & \\
1. Discharge against medical advice & \\
\hline
\end{tabular}

\section{Figures}




\section{9 patients with cirrhosis}
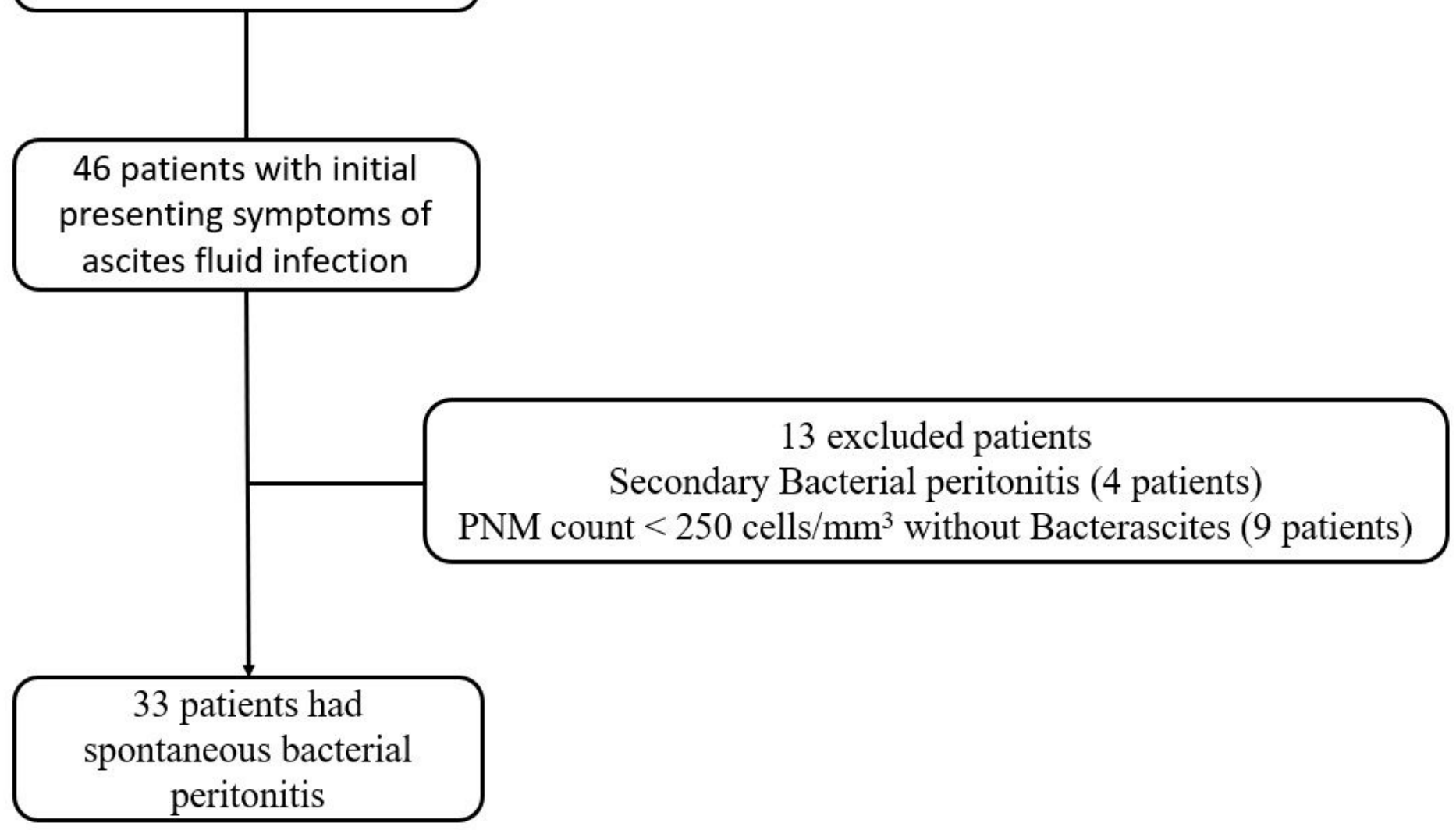

Figure 1

Flowchart of patients enrollment in the study. Abbreviations: PMN, polymorphonuclear leukocytes 